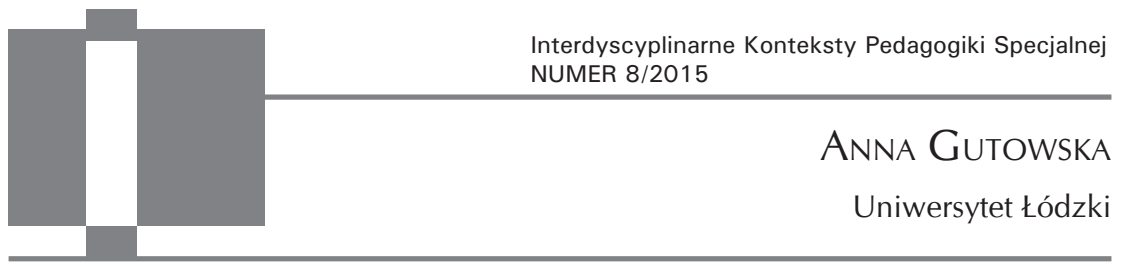

\title{
(Nie)pełnosprawna starość - przyczyny, uwarunkowania, wsparcie
}

\begin{abstract}
Aвstract: Gutowska Anna, Older people with disability - causes, determinants, support [(Nie)pełnosprawna starość - przyczyny, uwarunkowania, wsparcie ]. Interdyscyplinarne Konteksty Pedagogiki Specjalnej, nr 8, Poznań 2015. Pp. 9-33. Adam Mickiewicz University Press. ISBN 978-83-232-2902-5. ISSN 2300-391X.
\end{abstract}

In this article we concentrated on the problem of disability in old age. This study presents: old age, aging process, disability and consequences disability in old age. Reflections on the support of older people with disability located and the end.

KEY wORDs: old age, aging process, disability, older people with disability.

Wstęp

Zarówno problematyka niepełnosprawności, jak i starości jest przedmiotem zainteresowania wielu dyscyplin naukowych, lecz nadal są to zjawiska wymagające badań. Zmiany demograficzne towarzyszące współczesnemu człowiekowi ujawniają nowe obszary badawcze. Postęp cywilizacji, wzrost gospodarczy, przeobrażenia społeczne, intensywny rozwój medycyny to tylko niektóre czynniki, jakie doprowadziły do istotnych zmian demograficznych. Współcześnie w Polsce osoby starsze (w wieku 65 lat i więcej) sta- 
nowią około 13\% społeczeństwa. Dane prognostyczne Głównego Urzędu Statystycznego (2009) wskazują, że do 2035 r. liczba Polaków $\mathrm{w}$ tej grupie wiekowej wzrośnie i niemal co czwarty z nas będzie miał 65 lat i więcej ${ }^{1}$.

Wydłużenie ludzkiego życia nie zawsze idzie w parze z satysfakcjonującą sprawnością psychofizyczną. Sytuację seniorów często determinują niepełnosprawność i wielochorobowość. Badania GUS wykazują, że trudności przy wykonywaniu prac domowych wynikające ze stanu zdrowia deklaruje co trzeci 60 -latek, ponad $60 \%$ 70-latków i prawie $85 \%$ osób w wieku 80 lat i więcej². Zwiększa się także liczba osób niepełnosprawnych. Dane Narodowego Spisu Powszechnego z 2011 r. wskazują, że stanowią oni 12,2\% ludności, uznaje się jednak, że jest to liczba niedoszacowana ${ }^{3}$. Brakuje także badań diagnozujących populację niepełnosprawnych osób starszych (również tych, które nie posiadają prawnego orzeczenia).

Proces starzenia się jest nieuchronny zarówno w wymiarze indywidualnym, jak i społecznym. Dotyka on wszystkich ludzi - i tych zdrowych, sprawnych, i przewlekle chorych, niepełnosprawnych w różnych zakresach, rodzajach i stopniach. Pogłębiający się charakter zjawiska stanowi aktualnie jedno z najpoważniejszych wyzwań społecznych, gospodarczych i politycznych.

\section{Starzenie się i starość}

Starzenie się jest powszechnym i naturalnym procesem życiowym. Zmiany, które ze sobą niesie są stopniowe, ale nieodwracalne i uniwersalne, a co ważne dotyczą wielu sfer życia. Starość, zwana także późną dorosłością, wiekiem senioralnym, wiekiem podeszłym, "trzecim wiekiem”, jest okresem, który najczęściej klasyfikowany jest

1 Stan zdrowia ludności Polski w 2009 roku, GUS, Warszawa 2011.

2 Ibidem.

${ }^{3}$ Odpowiedzi na pytania dotyczące niepełnosprawności uzyskiwane były na zasadzie dobrowolności i deklaracji, co mogło rzutować na uzyskaną w NSP strukturę grupy osób niepełnosprawnych. 
w przedziale od 60.-65. roku życia do śmierci, ale nie ma jednoznacznej definicji tej fazy życia. Oznacza to brak zgodności co do tego, na podstawie jakich kryteriów granice wieku podeszłego powinny być wyznaczane. Różne kryteria przyjmuje się w naukach medycznych, polityce społecznej, psychologii, pedagogice czy socjologii. Nie są one jednak wyczerpujące ze względu na złożoność i wieloaspektowość tego zagadnienia.

W literaturze przedmiotu najczęściej stosuje się podział na wiek:

a) biologiczny - zmiany w funkcjonowaniu organizmu,

b) kalendarzowy - liczba przeżytych lat,

c) ekonomiczny - wiek zakończenia aktywności zawodowej,

d) społeczny - określany przyjmowanymi postawami i rolami społecznymi,

e) prawny - określa granice wieku poprodukcyjnego.

Najważniejsze zmiany w starzejącym się organizmie to:

a) zmiany morfologiczno-biochemiczne w zakresie komórek, tkanek, w składzie ciała i w płynach ustrojowych,

b) zmniejszenie rezerw narządowych,

c) zmniejszenie możliwości adaptacji organizmu do obciążeń fizycznych, biologicznych, psychicznych i społecznych oraz zachowania homeostazy,

d) zwiększenie chorobowości,

e) wzrost śmiertelności wraz z wiekiem ${ }^{4}$.

Pierwsze trzy elementy mają charakter obligatoryjny i składają się na proces fizjologicznego starzenia się, kolejne dwa wpisują się w patologiczny obraz starzenia się.

Jedną z trudniejszych kwestii w ocenie procesu starzenia się jest określenie granic starości. Jest to okres niejednorodny, w którym daje się wyróżnić kilka faz. Na przykład Światowa Organizacja Zdrowia wyodrębniła wśród osób starszych cztery grupy wiekowe:

${ }^{4}$ K. Duda, Proces starzenia się, [w:] Fizjologia starzenia się. Profilaktyka i rehabilitacja, red. A. Marchewka, Z. Dąbrowski, J.A. Żołądź, Wydawnictwo Naukowe PWN, Warszawa 2013, s. 4-5. 
a) wiek przedstarczy (łac. prasenium) - od 45 do 59 lat,

b) wczesna starość (III wiek) - od 60 do 74 lat, w tym young elder$l y$ - od 65 do 74 lat,

c) późna starość (old elderly) - od 75 do 89 lat, w tym „sędziwa starość" (IV wiek) - powyżej 80 lat,

d) długowieczność - powyżej 90. roku życia ${ }^{5}$.

Należy jednak zauważyć, że wiek kalendarzowy (chronologiczny), $\mathrm{z}$ powodu różnic $\mathrm{w}$ dynamice procesu starzenia się, nie pokrywa się z wiekiem biologicznym (czynnościowym), który jest wynikiem procesu starzenia się. Starzenie się, w ujęciu biologicznym, rozpoczyna się już między 30. a 40. rokiem życia. Mimo że ludzie starzeją się w różnym tempie i na różne sposoby, to powszechnym i nieuniknionym następstwem tego procesu jest postępujące $\mathrm{z}$ wiekiem pogarszanie się stanu zdrowia. Starzenie definiuje się często jako stopniowe pogorszenie funkcji wszystkich narządów i układów w organizmie, które utrudnia utrzymanie homeostazy. Sam proces starzenia się nie powoduje chorób, ale sprzyja występowaniu problemów zdrowotnych. Wśród zmian w organizmie, które wywołane są procesem starzenia, najczęściej wymienia się: zmniejszenie masy i siły mięśni, pogorszenie koordynacji psychoruchowej, wolniejsze reakcje ruchowe, pogorszenie funkcjonowania zmysłów ${ }^{6}$. Wielochorobowość, niepełnosprawność fizyczna, a często i umysłowa skutkują różnorodnymi ograniczeniami, nierzadko bólem i cierpieniem. Jednak starość to coś więcej niż pogorszenie kondycji fizycznej i psychicznej. Żyjący coraz dłużej seniorzy stanowią istotny element współczesnych społeczeństw, a ich aktywność społeczna może być niezwykle cennaa. Zachowanie dobrego stanu zdrowia seniorów jest więc nie tylko problemem pojedynczych jednostek, ale również całego społeczeństwa. Należy zdać sobie jednak sprawę

5 Ibidem, s. 3.

${ }^{6}$ K. Wieczorowska-Tobis, A. Neumann-Podczaska, Wpływ leków na sprawność funkcjonalną osób starszych na przykładzie upadków, [w:] Niesprawność u osób starszych. Zapobieganie - diagnostyka - terapia, red. A. Jakrzewska-Sawińska, Wielkopolskie Stowarzyszenie Wolontariuszy Opieki Paliatywnej Hospicjum Domowe, Poznań 2013, s. 38 . 
z tego, że zdecydowana większość osób starzeje się w sposób patologiczny, czyli chorując.

Zdrowo starzejących się ludzi jest zdecydowanie mniej. Szacuje się, że tylko około 8-10\% populacji osób starych nie choruje przewlekle i umiera ze starości, śmiercią naturalna7.

Pomyślne, pozytywne, optymalne starzenie się to terminy, które w dzisiejszej literaturze naukowej są żywo obecne. Wciąż zmienia się spojrzenie na starość, specjaliści coraz częściej podkreślają rolę edukacji, profilaktyki społecznej czy promocji zdrowia. Jednak jak twierdzi R.D. Hill, starość wciąż wiąże się z poważnymi wyzwaniami. Pogorszenie stanu zdrowia, niedołęstwo, strata osób bliskich, zmiana ról społecznych to nowe wyzwania dla człowieka w starszym wieku ${ }^{8}$. Można i należy zatem szukać sposobów, aby nie tylko żyć jak najdłużej, ale także do ostatnich chwil zachować jak największe poczucie dobrostanu.

\section{Niepełnosprawność, niesprawność, niesamodzielność - ustalenia definicyjne}

Dyskusje i ustalenia terminologiczne dotyczące niepełnosprawności trwają od lat i wydają się nie mieć końca. Czym jest niepełnosprawność? Odpowiedź nie jest prosta ze względu na wieloznaczność i wielopłaszczyznowość pojęcia oraz różne sposoby jej klasyfikowania. Niezależnie od przyjętej definicji niepełnosprawności należy pamiętać, że istnieją różne jej rodzaje, dlatego trudno mówić o osobach niepełnosprawnych jako jednolitej grupie napotykającej podobne problemy ${ }^{9}$.

Ustalenia definicyjne rozpocznę od wyjaśnienia pojęć: niesprawność, niesamodzielność i niepełnosprawność.

${ }^{7}$ K. Duda, op. cit.

${ }^{8}$ R.D. Hill, Pozytywne starzenie się, Laurum, Warszawa 2009, s. 181.

9 P.S. Czarnecki, Praca socjalna, Difin, Warszawa 2013. 
Niesprawność (impariment) rozumiana jest jako każda utrata sprawności lub nieprawidłowość w budowie czy funkcjonowaniu organizmu pod względem psychologicznym, psychofizycznym lub anatomicznym. Sprawność (w opozycji do niesprawności) jest kategorią złożoną, wieloznaczną, obecną w wielu dyscyplinach naukowych. W naukach technicznych jest cechą funkcjonowania rzeczy i oznacza stosunek energii wydanej do pobranej. Sprawność ocenia się, stosując różne kryteria, w tym: skuteczność, korzystność i ekonomiczność. Podstawową postacią sprawnego działania jest skuteczność, a działanie skuteczne to takie, które prowadzi do osiągnięcia ustalonych celów ${ }^{10}$. W odniesieniu do działania człowieka sprawność określana jest jako „zdolność do wykonywania określonych czynności”11 i dotyczy zarówno ciała, jak i umysłu. Podobnie jak niesprawność, niesamodzielność najłatwiej wyjaśnić w opozycji do samodzielności. Samodzielność to „swoista dyspozycja osoby do kierowania własnym postępowaniem"12. Rozpatrywana może być jako postawa życiowa, nierozerwalnie związana $\mathrm{z}$ autonomią, niezależnością i samostanowieniem, ale także jako potrzeba psychiczna, „,niejako naturalna tendencja człowieczego dążenia do wolności, a jednocześnie wyraz tej wolności"13. Samodzielność rozumiana jest także jako forma aktywności, która przejawia się w niezależności myślenia, działania, samoobsługi, zaspokajania potrzeb. Niesamodzielność jest więc kategorią wielowymiarową i wiąże się z różnymi problemami osób znajdujących się w sytuacji choroby, niepełnosprawności, ale też innych kryzysów. Niesamodzielność powoduje konieczność korzystania z pomocy innych, a prowadzone działania rehabilitacyjne, terapeutyczne nierzadko umożliwiają osobie niesamodzielnej doświadczanie siebie i świata.

Przez niesamodzielność rozumiem więc niemożność samodzielnego wykonywania codziennych czynności i konieczność korzysta-

${ }^{10}$ www.ur.edu.pl/file/5671/04.pdf [15.05.2015].

11 Stownik języka polskiego, red. W. Doroszewski, PWN, Warszawa 1963, s. 628.

12 Niesamodzielność. Studia z pedagogiki specjalnej, red. M. Sekułowicz, M. Oleniacz, Wydawnictwo Naukowe DWS, Wrocław 2012, s. 9.

13 Ibidem. 
nia z pomocy osób trzecich. Należy traktować ją jako niezdolność do samodzielnej egzystencji, powodującej konieczność stałej lub długotrwałej opieki i pomocy. Niesamodzielność może wynikać z uszkodzeń organizmu, stanów chorobowych czy starczej niewydolności organizmu. Pojęcie to jest często używane dla określenia trudności, które ujawniają się w okresie starości. Jak zauważa Z. Lewandowska-Szweda, częstotliwość występowania niesamodzielności jest wyższa wśród osób po 80. roku życia niż u osób młodszych. Najczęściej potrzebują one pomocy przy wykonywaniu czynności wymagających siły i sprawności fizycznej, takich jak: przynoszenie zakupów, sprzątanie mieszkania, przygotowywanie posiłków, dalsze wyjścia z domu. Konieczność korzystania z pomocy osób trzecich przy zaspokajaniu podstawowych potrzeb jest skorelowana $z$ wiekiem ${ }^{14}$.

Najszersze znaczenie ze wszystkich trzech omawianych terminów ma pojęcie „niepełnosprawność”. Pedagogika specjalna proponuje wiele definicji niepełnosprawności, ale $\mathrm{z}$ analizy literatury wynika, że nie ma jednoznacznej i wyczerpującej propozycji. W Polsce obowiązuje definicja, która niepełnosprawność ujmuje jako trwałą lub okresową niezdolność do wypełniania ról społecznych z powodu stałego lub długotrwałego naruszenia sprawności organizmu, w szczególności powodującą niezdolność do pracy ${ }^{15}$. Za osobę niepełnosprawną uznaje się zaś taką, której stan fizyczny lub/i psychiczny trwale lub okresowo utrudnia, ogranicza lub uniemożliwia wypełnianie zadań życiowych i ról społecznych zgodnie z normami prawnymi i społecznymi ${ }^{16}$.

Natomiast Światowa Organizacja Zdrowia w 1980 r. za osobę niepełnosprawną uznała tę, u której istotne uszkodzenie i obniżenie sprawności funkcjonowania organizmu powoduje utrudnienie, ograniczenie lub uniemożliwienie wykonywania zadań życiowych

14 www.ue.katowice.pl/uploads/media/20_Z.Szweda-Lewandowska_Modele_opieki....pdf [15.05.2015].

15 Ustawa z dnia 27 sierpnia 1997 r. o rehabilitacji zawodowej i społecznej oraz zatrudnieniu osób niepełnosprawnych art. 2 pkt 10, Dz.U. z 2011 r., nr 127, poz. 721 z późn. zm.

16 Ibidem. 
i wypełniania ról społecznych, biorąc pod uwagę jej wiek, płeć, czynniki społeczne, środowiskowe i kulturowe ${ }^{17}$. Definicję tę zmodyfikowano w 1997 r., uznając, że niepełnosprawni to osoby o naruszonej sprawności psychofizycznej powodującej ograniczenie funkcjonalne sprawności lub aktywności życiowej w stopniu utrudniającym pełnienie właściwych dla nich ról społecznych. W 2007 r. dokonano kolejnej zmiany definicyjnej uznając, że „niepełnosprawność to wielowymiarowe zjawisko wynikające ze wzajemnych oddziaływań między ludźmi a ich fizycznym i społecznym otoczeniem, efekt barier napotykanych $\mathrm{w}$ otoczeniu fizycznym i społecznym"18.

Współczesne definicje niepełnosprawności oscylują pomiędzy ujęciem tego zagadnienia w sposób czysto biologiczny (uszkodzenia narządów i ich czynności, które powodują naruszenie lub obniżenie sprawności, a co za tym idzie - ograniczenie funkcjonowania całego organizmu) i czysto społeczny (konsekwencje uszkodzenia i obniżenie sprawności funkcjonowania w różnych sferach życia). Tworzone do różnych celów podkreślają w zależności od potrzeb aspekty prawne, kulturowe czy ekonomiczne. Wydaje się zatem, że dopóki nie zostaną ustalone wyraźne granice między zdrowiem a chorobą oraz chorobą a niepełnosprawnością trudno będzie o kompromis w tej kwestii.

Model medyczny i społeczny niepełnosprawności połączono, tworząc model biopsychospołeczny i dokonując jej najnowszej klasyfikacji zaproponowanej w Międzynarodowej Klasyfikacji Funkcjonowania Niepełnosprawności i Zdrowia (International Classification of Functioning, Disability and Health - ICF 2001) ${ }^{19}$.

Podstawowe pojęcia zastosowane w tej klasyfikacji to zdrowie (dobrostan), funkcjonowanie człowieka (aktywność, uczestnictwo

17 International Classification of Impairments, Disabilites and Handicaps, WHO, Genewa 1980.

${ }_{18}$ Międzynarodowa Klasyfikacja Funkcjonowania, Niepetnosprawności i Zdrowia (ICF) oraz jej zastosowanie, Centrum Systemów Informacyjnych Ochrony Zdrowia, Warszawa 2007.

${ }^{19}$ International Classification of Functioning, Disability and Health, WHO, Genewa 2001, s. 110-160. 
w życiu społecznym) i niepełnosprawność (utrudnienie, ograniczenie lub uniemożliwienie aktywności człowieka i jego uczestnictwa w życiu społecznym) ${ }^{20}$.

Wśród elementów funkcjonowania człowieka wymieniono:

a) funkcjonowanie organizmu obejmujące wszystkie funkcje (czynności) i strukturę (budowę) narządów ciała ludzkiego;

b) aktywność człowieka obejmującą takie formy działalności jak czynności samoobsługowe, prace domowe, nauka czy praca zawodowa;

c) uczestnictwo w życiu społecznym i relacje ze środowiskiem społecznym, innymi ludźmi.

Klasyfikacja uwzględnia również czynniki kontekstowe, które składają się na sytuację życiową danej osoby (zarówno te środowiskowe, jak i indywidualne). Człowiek postrzegany jest tu jako istota biologiczna, aktywna, działająca i wypełniająca określone czynności i zadania życiowe, członek określonej grupy społecznej, a więc osoba funkcjonująca zarówno na poziomie biologicznym, indywidualnym, jak i społecznym. Niepełnosprawność jest zatem wyrazem niższego poziomu funkcjonowania $w$ tych trzech wymiarach lub niektórych z nich. Na poziomie biologicznym niepełnosprawność może być przejawem zniesienia, ograniczenia lub zaburzenia funkcji organizmu w zależności od stopnia i zakresu uszkodzenia organów, narządów. Na poziomie jednostkowym to ograniczenie aktywności, a na poziomie społecznym - ograniczenie uczestnictwa w życiu społecznym $^{21}$. W takim rozumieniu niepełnosprawność jest wielowymiarowym zjawiskiem wzajemnych relacji między czynnikami zdrowotnymi (choroby, urazy, zaburzenia), środowiskowymi (m.in. prawo, polityka społeczna, architektura) i jednostkowymi (m.in. wiek, płeć, poziom wykształcenia, cechy osobowościowe) ${ }^{22}$.

${ }^{20}$ International Classification of Functioning, Disability and Health, Genewa 2001.

${ }^{21}$ T. Majewski, Międzynarodowa Klasyfikacja Funkcjonowania, Niepetnosprawności i Zdrowia, „Praca i Rehabilitacja Niepełnosprawnych” 2008, nr 3-4(119-120), s. 8-10.

${ }^{22}$ L. Januszko, Niepetnosprawność - aspekt epidemiologiczny $i$ społeczny, [w:] Niepetnosprawni na progu wejścia Polski do Unii Europejskiej, red. M. Waszkowski, Polskie Towarzystwo Walki z Kalectwem, Warszawa 2004, s. 67-73. 
W praktyce stosuje się także pojęcie niepełnosprawności prawnej, związanej z uzyskaniem przez daną osobę orzeczenia o stopniu niepełnosprawności. Jednak nie wszystkie osoby niepełnosprawne występują z wnioskiem o ustalenie jej stopnia i funkcjonują jako osoby z niepełnosprawnością biologiczną.

Na potrzeby niniejszego artykułu można przyjąć, że pojęcie „niepełnosprawność", ujmowane szeroko, zawiera w sobie także terminy „niesprawność” i „niesamodzielność”, choć nie należy mylić procesu, jakim jest choroba przewlekła czy terminalna, ze stanem, jakim jest niepełnosprawność. Mogą one prowadzić do istotnych ograniczeń w funkcjonowaniu, pełnieniu ról społecznych i wykonywaniu zadań życiowych, a w konsekwencji do niepełnosprawności, ale nie muszą.

Warto dodać, że na odbiór i przeżywanie niepełnosprawności/ niesprawności/niesamodzielności wpływa wiele czynników, m.in.: zakres i sposób uszkodzenia struktury i/lub funkcji, subiektywny odbiór niepełnosprawności, jej skutków, oddziaływania służby zdrowia, pomocy społecznej i systemu orzecznictwa.

\section{Niepełnosprawne osoby starsze}

Narodowy Spis Powszechny z 2002 r. ujawnił, że w Polsce żyje ponad $5 \mathrm{mln} 456$ tys. osób niepełnosprawnych, co stanowi ponad $14 \%$ ogółu ludności. Występowanie niepełnosprawności wzrasta z wiekiem, zwłaszcza niepełnosprawności fizycznej. Jak pisze Arkadiusz Przybyłka, „obejmuje ona w Polsce 43,6\% populacji w wieku 60 lat, 63,4\% - w wieku 70 lat i 83,7\% - powyżej lat 80"23. Inne dane ujawniają, że w przedziale wiekowym 60-69 lat niepełnosprawność dotyczyła blisko 39\% Polaków, w przedziale 70-79 - prawie 41\%, natomiast powyżej 80 lat - prawie $47 \%$ osób ${ }^{24}$.

23 A. Przybyłka, Problemy zdrowotne ludzi starych. Wybrane zagadnienia, „Polityka Społeczna" 2002, nr 8, s. 14.

24 B. Balcerzak-Paradowska, Sytuacja osób niepetnosprawnych w Polsce, [w:] Raport IPiSS, nr 22, Warszawa 2002, s. 165-197. 
Niepełnosprawne osoby starsze stanowią bardzo zróżnicowaną grupę. Są to zarówno osoby z niepełnosprawnością wrodzoną lub nabytą we wcześniejszych fazach życia, jak i te, które stały się niepełnosprawne w okresie późnej dorosłości, na skutek ujawnienia się z wiekiem różnych schorzeń prowadzących do obniżenia lub braku sprawności. Pierwsza grupa to osoby, które weszły w fazę starości, już przystosowane do niepełnosprawności, która była obecna w ich życiu od urodzenia. Problemem mogą tu być następstwa procesu starzenia się nakładające się na trudności wynikające z wcześniejszych dysfunkcji. Natomiast wśród osób z niepełnosprawnością nabytą w późnym wieku problemy nakładają się na skutki starzenia się, np. utratę małżonka, zaprzestanie pracy zawodowej, utratę pozycji społecznej, i z tego powodu są odczuwane bardziej dotkliwie. Między starzeniem się a niepełnosprawnością dochodzi do wzajemnych interakcji i intensyfikacji strat ${ }^{25}$. Jak pisze M. Kilian, subpopulacje osób niepełnosprawnych starzeją się szybciej niż całościowa ludność Polski ${ }^{26}$. "Zgodnie z dowiedzioną zależnością, powszechność występowania niepełnosprawności w starszym wieku będzie wzrastać w miarę postępowania procesu starzenia się społeczeństwa, a potrzeby powiększającej się grupy niepełnosprawnych seniorów będą wywierać na nie coraz większy nacisk"27.

Według Światowej Organizacji Zdrowia wśród osób starszych może występować ciąg przyczynowo-skutkowy: choroba - uszkodzenie - niesprawność - inwalidztwo. A. Zych podaje zestawienie amerykańskich geriatrów, którzy niepełnosprawność osób starszych sklasyfikowali w postaci kilkunastu „I", spośród których autor wymienił:

- Immobility - brak mobilności i/lub brak możliwości poruszania się prowadzące do niepełnosprawności ruchowej;

${ }^{25}$ M. Kilian, Geragogika specjalna w dobie starzenia się społeczeństw, [w:] Dylematy (niepetno)sprawności - rozważania na marginesie studiów kulturowo-społecznych, red. M. Dycht, L. Marszałek, Wydawnictwo Salezjańskie, Warszawa 2009, s. 316-341.

26 Ibidem.

27 Ibidem. 
- Immunological deficency - obniżenie bądź brak odporności immunologicznej;

- Impotence - impotencja płciowa, niekiedy towarzysząca innym chorobom, np. depresji, prostacie czy chorobie Alzheimera;

- Inanition - wycieńczenie spowodowane niedożywieniem, wyniszczeniem organizmu i/lub marazm;

- Incontience - zaburzenia zwieraczy, tj. nietrzymanie moczu i/lub stolca;

- Insomnia - bezsenność;

- Instability - niestabilność, zaburzenia równowagi, lokomocji, które mogą prowadzić do upadków;

- Intellectual impairment - niepełnosprawność, ograniczenie lub upośledzenie umysłowe, najczęściej pod postacią zaburzeń otępiennych;

- Isolation - izolacja społeczna ${ }^{28}$.

Częstą przyczyną trudności w okresie starości są tzw. zespoły geriatryczne. Definiuje się je jako „pogarszającą zdrowie/zwiększającą chorobowość starych osób konstelację objawów i oznak, wynikających często z nieznanych jeszcze interakcji szeregu chorób i wieku" ${ }^{29}$. Do wielkich zespołów geriatrycznych zalicza się:

a) zaburzenia zwieraczy - nietrzymanie moczu i stolca. Nietrzymanie moczu polega na bezwiednym, niekontrolowanym oddawaniu moczu i jest najczęściej skutkiem fizjologicznych zmian, wad w układzie moczowym lub następstwem różnych chorób. Możliwe jest współwystępowanie wielu przyczyn tego zjawiska. Jest to dominujący problem starszych kobiet (stanowią 85\% osób nietrzymających moczu), który może towarzyszyć obniżeniu narządów rodnych (pochwy i macicy). W Polsce ponad $4 \mathrm{mln}$ osób cierpi z tego powodu. Nietrzymanie stolca, czyli niemożność utrzymania zawartości jelit i wydostawania się treści kałowych bez kontroli, występuje

28 A.A. Zych, B.M. Zych, Przekraczając "smuge cienia". Szkice z gerontologii i tanatologii, Wydawnictwo Naukowe „Śląsk”, Katowice 2013, s. 60-61.

${ }^{29}$ K. Duda, op. cit., s. 6. 
nieco rzadziej. Jest to często zaburzenie odwracalne. Stanowi jedną z przyczyn powstawania odleżyn lub trudności w ich gojeniu. Zaburzenia zwieraczy powodują problemy z utrzymaniem higieny, są też często przyczyną innych zaburzeń, np. infekcji, odleżyn, zaburzeń snu. Zaburzenia zwieraczy to problem zarówno medyczny, jak i społeczny (prowadzący do zaniechania kontaktów społecznych, zaprzestania wychodzenia z domu) czy ekonomiczny;

b) zaburzenia otępienne - otępienie jest zespołem spowodowanym chorobą mózgu, zwykle o charakterze przewlekłym lub postępującym, w którym zaburzone są także wyższe funkcje korowe, jak: pamięć, myślenie, orientacja, rozumienie, liczenie, zdolność uczenia się, język i ocena. Uszkodzeniu funkcji poznawczych towarzyszy zwykle, a niekiedy je poprzedza, zmniejsżenie kontroli nad reakcjami emocjonalnymi i społecznymi, zachowaniem i motywacją. Otępienie powoduje znaczący spadek funkcji intelektualnych i zwykle wpływa na podstawowe aktywności życiowe: jedzenie, ubieranie się, wydalanie, higienę osobistą ${ }^{30}$. Chorzy z otępieniem tracą nie tylko pamięć i sprawność funkcjonowania, ale najczęściej także autonomię. W Polsce co dziesiąta osoba po 65. roku życia, tj. około 500 tys. osób, cierpi na różne formy otępienia ${ }^{31}$. Do najczęściej występujących zespołów otępiennych zalicza się: chorobę Alzheimera, chorobę Parkinsona i demencję typu miażdżycowego. Choroba Alzheimera stanowi ponad połowę wszystkich chorób otępiennych zdiagnozowanych w populacji osób starych. W większości przypadków rozpoczyna się po 60. roku życia i ma w początkowym stadium obraz utajony. Postępujący proces otępienia może trwać kilka, a nawet kilkadziesiąt lat i przebiega w kilku stadiach. Zazwyczaj prowadzi do całkowitej utraty samodzielności, a w końcu do

30 A. Bilikiewicz, Psychiatria. Podręcznik dla studentów medycyny, Wydawnictwo Lekarskie PZWL, Warszawa 2006.

${ }^{31}$ A.A. Zych, B.M. Zych, op. cit. 
śmierci. Statystycznie częściej zapadają na nią kobiety. Choroba Alzheimera polega na zaburzeniach czynności części mózgu, które są odpowiedzialne za funkcje poznawcze. Jej główne objawy to: utrata zdolności poznawczych - zaburzenia funkcji pamięciowych, upośledzenie zdolności do uczenia się nowych informacji lub przypominania zapamiętanych wcześniej; afazja - problemy z artykulacją mowy; apraksja niezdolność do wykonywania złożonych czynności ruchowych mimo zachowanych funkcji motorycznych; agnozja niemożność rozpoznawania i identyfikowania przedmiotów mimo zachowanych funkcji sensorycznych; zaburzenia zdolności myślenia, zaburzenia w zakresie planowania, organizowania, przestrzegania sekwencji, abstrahowania; dezorientacja w czasie i przestrzeni, zaburzony rytm dnia i nocy; postępujące zniedołężnienie, problemy $\mathrm{z}$ radzeniem sobie z codziennymi czynnościami, zaburzona dbałość o higienę osobistą, brak kontroli zwieraczy; bezradność, tracenie kontaktu z rzeczywistością; niekiedy zmiany charakterologiczne, agresja, gniew ${ }^{32}$;

c) depresja - może mieć podłoże organiczne, ale nie musi. Czynnikiem ją wyzwalającym może być także ciężkie przeżycie, np. śmierć współmałżonka. Zmieniająca się sytuacja, zmniejszający się krąg krewnych, znajomych może prowadzić do poczucia osamotnienia, dekompensacji mechanizmów przystosowawczych, a w konsekwencji pogorszenia zdrowia fizycznego i psychicznego. Rozpowszechnienie zaburzeń depresyjnych po 65. roku życia sięga 15-20\%, a wśród seniorów korzystających z pomocy medycznej - aż 30\% ${ }^{33}$. S. Pużyński wśród czynników sprzyjających występowaniu zaburzeń depresyjnych $w$ wieku podeszłym wymienia: brak aktywności, bezczynność, izolację związaną z przejściem na emeryturę,

32 A. Bilikiewicz, op. cit.

33 S. Pużyński, Depresje i zaburzenia afektywne, Wydawnictwo Lekarskie PZWL, Warszawa 2009. 
przerwaniem pracy zawodowej; zmianę warunków mieszkaniowych lub miejsca zamieszkania, pobyt w placówkach opiekuńczych; pogorszenie sytuacji materialnej; osamotnienie, brak wsparcia ze strony bliskich; utratę osób najbliższych (śmierć współmałżonka, odejście dzieci); przewlekłe choroby somatyczne; obecność zaburzeń otępiennych ${ }^{34}$. Przyczyny depresji w późnej dorosłości można podzielić na cztery grupy: psychologiczne (etiologia reaktywna); somatyczne (choroby somatyczne, lęki i zmiany naczyniowe); organiczne (zmiany ośrodkowego układu nerwowego); endogenne (nawracające zaburzenia afektywne). Ostre rozgraniczenie tych przyczyn jest najczęściej trudne, a postępowanie lecznicze powinno mieć charakter kompleksowy, niezależnie od etiologii. Objawy w depresji typowej można podzielić na: podstawowe (osiowe) i nieswoiste (wtórne). Do pierwszych zalicza się: obniżenie nastroju - stan smutku, przygnębienia, niekiedy zobojętnienia, niezdolność do przeżywania radości; osłabienie tempa procesów psychicznych i ruchowych, nazywane zahamowaniem psychoruchowym - spowolnienie tempa myślenia, osłabienie pamięci, poczucie niesprawności intelektu, spowolnienie ruchów lokomocyjnych, niekiedy całkowite zahamowanie ruchowe (osłupienie), niepokój; objawy somatyczne i zaburzenia rytmów biologicznych - zaburzenia rytmu snu i czuwania, wahania samopoczucia w ciągu dnia, napięciowe bóle głowy, wysychanie błon śluzowych jamy ustnej, brak łaknienia; lęk - „wolnopłynący”, utrzymujący się niemal stale, wykazujący falujące nasilenie, może osiągać znaczne rozmiary i ujawniać się w sferze ruchowej (podniecenie) lub w postaci stanów paniki ${ }^{35}$. Do objawów nieswoistych (wtórnych) zalicza się: depresyjne zaburzenia myślenia - negatywna ocena własnej osoby, stanu zdrowia, przeszłości i przyszłości, w natężeniu: urojenia nihilistyczne, winy, kary, grzeszności, katastroficzne

34 Ibidem, s. 83-84.

35 Ibidem. 
i hipochondryczne; zaburzenia aktywności złożonej - osłabienie kontaktów z otoczeniem, izolowanie się, zmniejszenie zakresu zainteresowań, samozaniedbywanie ${ }^{36}$. Dość częstym zjawiskiem $\mathrm{w}$ depresji jest także dysforia, której przejawem są: nastrój gniewu, zniecierpliwienie, rozdrażnienie. Dysforia może być przyczyną konfliktów z otoczeniem, ale także źródłem agresji i autoagresji, a nawet podejmowania prób samobójczych. Jak pisze A. Bilikiewicz, obraz depresji w wieku podeszłym, bez względu na etiologię, ma swoją specyfikę. Depresyjni seniorzy mają skłonność do lęku, zaburzeń snu i zgłaszania skarg hipochondrycznych. Ponadto mogą pojawić się urojenia depresyjne (poczucie winy, urojenia samooskarżające, urojenia grzeszności i potępienia), a także urojenia ksobne, prześladowcze czy nihilistyczne. Badania wykazują dwukrotnie wyższe ryzyko samobójstw wśród osób $\mathrm{z}$ depresją $\mathrm{w}$ wieku podeszłym niż w młodszej populacji ${ }^{37}$;

d) zaburzenia lokomocji i równowagi - szacuje się, że co trzecia osoba starsza przynajmniej raz $\mathrm{w}$ roku doświadcza upadku fizycznego, z czego około 10-15\% kończy się urazem, który skutkuje trudnościami z przemieszczaniem się. Upadek to niezamierzone przewrócenie się, którego bezpośrednią przyczyną jest nagłe zaburzenie równowagi. Około $2 / 3$ upadków ludzi starszych ma skutki śmiertelne. Badania wykazują, że upadki częściej zdarzają się starszym kobietom niż mężczyznom i częściej mają miejsce w instytucjach opiekuńczych niż w środowisku rodzinnym. Zaburzenia lokomocji i równowagi mogą prowadzić do złamań szyjki kości udowej (w większości u kobiet), czemu sprzyja osteoporoza. Przyczyn należy upatrywać zarówno $\mathrm{w}$ inwolucyjnych zmianach $\mathrm{w}$ układzie kostno-mięśniowym, mniejszej sprawności fizycznej, ale też we współwystępowaniu innych chorób, np. depresji, zespołów

${ }_{36}$ B. Żakowska-Wachelko, A. i T. Misztalscy, K. Czuma, Opiekun osób starszych, Śląskie Stowarzyszenie Ad Vitam Dignam, Katowice 2010, s. 147.

37 A. Bilikiewicz, op. cit. 
otępiennych, udarów mózgu. Główną przyczyną upadków osób starszych jest jednak mniejsza zdolność szybkiego przystosowania postawy ciała do nowych warunków ${ }^{38}$. Trudności w chodzeniu, wstawaniu z pozycji siedzącej, wchodzeniu i schodzeniu ze schodów, poruszaniu się po nierównych powierzchniach także sprzyjają upadaniu. Osoby starsze wykazujące zaburzenia lokomocji i równowagi wymagają dostosowania do swych potrzeb środowiska zamieszkania - powinny unikać śliskich powierzchni oraz stosować w pomieszczeniach uchwyty, balustrady, poręcze;

e) upośledzenia wzroku i słuchu - do najczęstszych zaburzeń wzroku spotykanych u osób starszych zalicza się: zaćmę (kataraktę), czyli utratę przejrzystości soczewki, jaskrę (glaukomę), prowadzącą do nieodwracalnych uszkodzeń nerwu wzrokowego, starcze zwyrodnienie plamki (powodujące stopniowe, postępujące zaburzenia widzenia centralnego), nadwzroczność starczą. Szacuje się, że około 30\% 70-latków ma upośledzony wzrok i już ponad połowa 80-latków ${ }^{39}$. Natomiast zaburzenia słuchu przybierają postać prezbioakuzji (starczego przytępienia słuchu) czy nawet głuchoty starczej. Wśród seniorów stwierdza się ponadto zmniejszenie odległości, z jakiej słyszane są dźwięki, pogorszenie zdolności lokalizacji dźwięków oraz słyszenie dodatkowych dźwięków (szumy uszne subiektywne). Procesy starzenia się są nieodwracalne i dotyczą wszystkich struktur drogi słuchowej. Upośledzenie wzroku i/lub słuchu w okresie starości istotnie wpływa na społeczne funkcjonowanie seniorów.

Cechą charakterystyczną wielkich zespołów geriatrycznych jest przewlekłość, wieloprzyczynowość i trudności w leczeniu. Najczęściej ograniczają one aktywność osób starszych, ich mobilność, aż w końcu powodują stopniową utratę niezależności. Mimo że nie

38 A.A. Zych, B.M. Zych, op. cit.

39 J. Halik, Inwalidztwo i niepetnosprawność wśród osób starszych, Instytut Spraw Publicznych, Warszawa 1997, s. 72. 
stanowią bezpośredniego zagrożenia życia, to w zdecydowany sposób wpływają na obniżenie jakości życia osób starszych.

Należy dodać, że brak autonomii, który może być skutkiem powyższych zaburzeń, zależność od innych osób powodująca przewlekły stres oraz postępująca niesprawność mogą prowadzić do powstawania innych chorób (m.in. choroby wieńcowej) i negatywnie wpływać na przebieg tych, na które zachorowanie nastąpiło wcześniej.

\section{Następstwa niepełnosprawności w starości}

Ważnym zagadnieniem dotyczącym niepełnosprawności osób starszych jest sprawność funkcjonalna, czyli sprawność w zakresie podstawowych (funkcjonowanie w mieszkaniu/domu) oraz złożonych (funkcjonowanie w środowisku) czynności życiowych. Przekłada się ona bezpośrednio na samodzielność i niezależność osoby starszej. Składają się na nią czynności związane z poruszaniem się po mieszkaniu/domu, ubieraniem się, jedzeniem, robieniem zakupów, przygotowywaniem posiłków, korzystaniem ze środków komunikacji miejskiej. Niesprawność funkcjonalna może wynikać zarówno z ograniczenia mobilności (niesprawność fizyczna), jak i zaburzeń w sferze psychicznej ${ }^{40}$.

Niepełnosprawność w starości cechuje:

a) dodatkowe obciążenie (handicap) powodujące rozdźwięk pomiędzy stopniem codziennej sprawności a oczekiwaniami seniora;

b) osłabienie (frailty) powodujące stan podwyższonego ryzyka rozwinięcia się niekorzystnych zdrowotnie zjawisk, jak łamliwość kości, osłabienie odporności, słabość psychofizyczna;

c) pogorszenie lub niemożność wykonywania pewnych czynności;

d) niemożność uczestnictwa w różnych sytuacjach życiowych.

${ }^{40}$ K. Wieczorowska-Tobis, A. Neumann-Podczaska, op. cit., s. 39. 
Skutki niepełnosprawności w starszym wieku niosą ze sobą ryzyko uszkodzeń o charakterze fizycznym i umysłowym. Osłabienie fizyczne, które może upośledzać ogólną zdolność motoryczną lub dotyczyć poszczególnych kończyn oraz osłabienie wyższych czynności nerwowych możę prowadzić do trudności w poruszaniu się, a także wypełnianiu codziennych zadań życiowych. Wpływa to na ograniczenie możliwości uczestnictwa w życiu społecznym. Ograniczona samodzielność może powodować poczucie utraty autonomii i niezależności, obniżać prestiż i przybliżać wizję śmierci. Istotnym doświadczeniem może być także skumulowanie doświadczeń straty, m.in. zdrowia, kondycji, a także bliskich (współmałżonka, krewnych, przyjaciół $)^{41}$. Wszystkie te czynniki mogą prowadzić do izolacji społecznej, samotności, dotkliwego poczucia osamotnienia, a w efekcie obniżenia poziomu jakości życia.

Niepełnosprawność i starość to zjawiska, którym nadal towarzyszy stereotypia i dyskryminacja. Jest ona widoczna w wielu sferach życia, zwłaszcza w obszarze ochrony zdrowia, rynku pracy, rynku konsumenckiego i partycypacji społecznej. Jej najczęstsze przejawy to: lekceważenie, agresja słowna, znęcanie się fizyczne i psychiczne, nadopiekuńczość, protekcjonalność, zaniedbanie, marginalizacja społeczna, odseparowanie, nadużycia finansowe, odmowa przyznania należnych świadczeń ${ }^{42}$.

Jak zauważa Z. Lewandowska-Szweda, większość wymienionych zachowań w stosunku do osób starszych wiążę się z gorszym traktowaniem. Jednak nadopiekuńczość jest często trudno dostrzegalna, gdyż różnica między chęcią pomagania a wyręczaniem seniora w wykonywaniu czynności, które może bez trudu i chce samodzielnie wykonywać, bywa trudna do zauważenia. Gorsze traktowanie osób starszych niekorzystnie wpływa na ich samopoczucie psycho-

${ }^{41}$ M. Straś-Romanowska, Późna dorosłość. Wiek starzenia się, [w:] Psychologia rozwoju człowieka. Charakterystyka okresów życia człowieka, red. B. Harwas-Napierała, J. Trempała, Wydawnictwo Naukowe PWN, Warszawa 2004.

${ }^{42}$ www.instytutobywatelski.pl/17845/lupa-instytutu/ageizm-dyskryminacja-ze-wzgledu-na-wiek [5.05.2015]. 
fizyczne, obniża jakość życia i niekiedy prowadzi do ulegania tym stereotypom przez samych seniorów ${ }^{43}$.

\section{Wybrane możliwości wsparcia}

Niepełnosprawna starość często niesie ze sobą konieczność pomocy i wsparcia. W literaturze przedmiotu wsparcie społeczne odnosi się zwykle do formalnych i nieformalnych związków międzyludzkich. W takim ujęciu jest to dostępne człowiekowi wsparcie wynikające $\mathrm{z}$ jego więzi społecznych z innymi ludźmi, grupami, zbiorowościami ${ }^{44}$. Wsparcie nie jest zatem możliwe bez udziału innych ludzi, a jego efektywność w dużej mierze uzależniona jest od potrzeb i możliwości wspieranego i wspierającego. Dotyczy to zarówno instytucji, profesjonalnych opiekunów wykonujących swoje obowiązki w ramach określonego systemu, jak i opiekunów nieformalnych, najczęściej członków rodziny.

Obserwowany wzrost zapotrzebowania na usługi opiekuńcze wobec niesamodzielnych seniorów ma uzasadnienie $w$ danych demograficznych oraz zachodzących przemianach społecznych, takich jak: osłabienie więzi rodzinnych, zanik rodziny wielopokoleniowej, niska liczba potomstwa, wzrost liczby gospodarstw jednoosobowych, osłabienie więzi lokalnych, migracje, marginalizacja, izolacja społeczna, ubóstwo. Obecnie około $30 \%$ osób powyżej 65. roku życia wymaga pomocy przy wykonywaniu podstawowych prac domowych i czynnościach samoobsługowych i już około $60 \%$ powyżej 80 lat $^{45}$.

W polskiej rzeczywistości podstawową "instytucją opiekuńczą" działającą w celu pomocy/wsparcia osób starszych jest rodzina ${ }^{46}$. Jak pisze B. Szatur-Jaworska na podstawie wyników badań Pol-

\section{Ibidem.}

44 A. Kacperczyk, Wsparcie społeczne w instytucjach opieki paliatywnej i hospicyjnej, Wydawnictwo Uniwersytetu Łódzkiego, Łódź 2006.

45 Stan zdrowia i potrzeby..., op. cit.

46 Ibidem. 
Senior, „najbliższa rodzina - w tym głównie pokolenie dzieci - jest najważniejszym źródłem pomocy dla ludzi starych. Rola osób spoza tego kręgu jest nieznaczna i najbardziej widoczna w przypadku wsparcia psychicznego. Potencjał pomocy ze strony przedstawicieli zawodów pomocowych (opiekunka, pielęgniarka środowiskowa, pracownik socjalny) postrzegany jest przez ludzi starych jako marginalny, co dowodzi, że w przypadku życiowych trudności właściwie nie dostrzegają oni alternatywy dla rodziny ${ }^{47}$. Także inne badania dowodzą, że rodzina jest dla seniorów najbardziej oczekiwanym dostawcą usług opiekuńczych.

Na podstawie dostępnych polskich badań, głównie EUROFAM$\mathrm{CARE}^{48}$ prowadzonych w latach 2003-2004, ich liczbę oszacowano na około $2 \mathrm{mln}$, z czego większość stanowiły kobiety w wieku 50-60 lat. Ujawniono, że najliczniejszą grupę opiekunów osób starszych stanowią ich dzieci $(51,1 \%)$, zdecydowanie rzadziej małżonkowie $(18,2 \%)$, synowe i zięciowie $(13,4 \%)$ oraz wnuki $(6,6 \%)$. Pozostali członkowie rodziny bardzo rzadko pełnią rolę opiekunów. Jak argumentuje E. Bojanowska, taki model opieki nad osobami starszymi wynika z jednej strony ze struktury demograficznej polskiej rodziny (stosunkowo duża liczba dzieci), z drugiej zaś - z preferowanego modelu opieki nad najstarszymi członkami rodziny (opieka pełniona przez najbliższą rodzine, przede wszystkim w domu $)^{49}$.

Badanie Polskiego Towarzystwa Gerontologicznego, cytowane przez P. Czekanowskiego, pokazało, że 60\% osób starszych korzy-

47 B. Szatur-Jaworska, Formy życia rodzinnego ludzi starych, „Polityka Społeczna” 2011, numer specjalny; Aspekty medyczne, psychologiczne, socjologiczne i ekonomiczne starzenia się ludzi w Polsce, red. P. Błędowski, PolSenior, Warszawa 2011, s. 17.

48 Projekt „Services for Supporting Family Carers of Elderly People in Europe: Characteristics, Coverage and Usage - EUROFAMCARE" był realizowane w ramach 5. Programu Ramowego UE. Celem projektu, przeprowadzonego w latach 2003-2005, była ocena opiekunów rodzinnych ludzi starych w Europie pod względem dostępności, znajomości, korzystania i akceptowania świadczeń wspierających pełnienie rodzinnej opieki nad seniorami.

49 E. Bojanowska, Opieka nad ludźmi starszymi, [w:] Przygotowanie do starości. Polacy wobec starzenia się, red. P. Szukalski, Fundacja Instytutu Spraw Publicznych, Warszawa 2009, s. 29. 
sta ze wsparcia młodego pokolenia w zakresie prac domowych, niemal co druga osoba starsza korzysta $\mathrm{z}$ pomocy w robieniu zakupów i załatwianiu spraw urzędowych, w 41\% w zakresie opieki pielęgnacyjnej ${ }^{50}$.

Problem opieki rodziny nad niesprawnym, starszym jej członkiem zasygnalizowano również $\mathrm{w}$ dokumencie przygotowanym w 2012 r. przez Rządową Radę Ludnościową, w którym zwrócono uwagę na jej coraz bardziej ograniczone możliwości' ${ }^{51}$. Według J. Hrynkiewicz „potencjał opiekuńczy rodziny w Polsce, rozumiany jako zdolność rodziny do świadczenia opieki swoim starym, niesamodzielnym i niepełnosprawnych członkom, z przyczyn demograficznych, ekonomicznych i społecznych zmniejsza się. Rodziny stają się mniej liczne, kontakty w rodzinach mniej intensywne, następuje osłabienie więzi, w zasadzie rozpadły się rodziny wielopokoleniowe, zanikają kręgi rodzinne. W Polsce utrzymuje się wciąż bardzo wysoki poziom emigracji zarobkowej, tak wewnętrznej, jak i zewnętrznej. Liczba osób zobowiązanych i zdolnych do udzielenia opieki z przyczyn demograficznych sukcesywnie będzie się zmniejszać. Potencjał opiekuńczy rodziny zależy od jej wielkości, struktury oraz od statusu społeczno-ekonomicznego" ${ }^{52}$.

Alternatywą dla nieformalnych usług opiekuńczych są te o charakterze instytucjonalnym - usługi opiekuncze świadczone w środowisku zamieszkania (finansowane przez Miejskie i Gminne Ośrodki Pomocy Społecznej lub wybrane organizacje pozarządowe), domy dziennego pobytu, zakłady opiekuńczo-lecznicze, domy pomocy społecznej. Ustawa o pomocy społecznej wskazuje, że pomoc w formie usług przysługuje osobom samotnym, które z racji wieku, choroby, niepełnosprawności lub innej przyczyny wymagają pomocy innych osób, a są jej pozbawione. Usługi opiekuńcze mogą też być

${ }^{50}$ P. Czekanowski, Rodzina w życiu osób starszych i osoby starsze w rodzinie, [w:] Polska starość, red. B. Synak, Wydawnictwo Uniwersytetu Gdańskiego, Gdańsk 2002, s. 164 .

51 O sytuacji ludzi starszych, red. J. Hrynkiewicz, Rządowa Rada Ludnościowa, Warszawa 2012.

52 Ibidem, s. 12-13. 
przyznane osobom mieszkającym w rodzinie, w przypadku gdy rodzina nie może takiej pomocy zapewnić53. Dom pomocy społecznej jest formą pomocy oferowaną w sytuacjach, gdy inny rodzaj wsparcia nie może być zapewniony lub jest niewystarczający w stosunku do potrzeb danej osoby. Dom pomocy społecznej świadczy usługi bytowe, opiekuńcze, wspomagające i edukacyjne według standardu obowiązującego dla każdego typu domu ${ }^{54}$.

W obecnych warunkach konieczne wydaje się opracowanie i wdrożenie takiego modelu wsparcia osób w podeszłym wieku, który byłby skuteczny i nadążałby za dynamicznie następującymi zmianami. Obie formy wsparcia: instytucjonalna i pozainstytucjonalna muszą być komplementarne i nie ograniczać się do fragmentarycznych oddziaływań w wybranych obszarach, resortach, systemach. Instytucjonalne formy pomocy osobom w podeszłym wieku nadal nie są dostępne dla wszystkich chętnych - czas oczekiwania na miejsce w placówce wynosi od kilku miesięcy do nawet kilku lat. Widoczne są niedostatki w tym zakresie. Brakuje także działań wspierających system rodzinny. Pamiętając o tym, że to nadal rodzina jest główną „instytucją opiekuńczą”, należy stworzyć jej odpowiednie warunki do realizacji funkcji opiekuńczych i pielęgnacyjnych. Wsparcie rodziny, opiekunów nieformalnych sprawujących opiekę nad niesamodzielnym seniorem wydaje się tak samo ważne jak bezpośrednie udzielanie pomocy tej osobie.

\section{Zakończenie}

Rosnąca liczba osób starszych, w tym osób niepełnosprawnych, stanowi poważne wyzwanie dla otoczenia. Konieczne jest zatem zwrócenie uwagi na problemy tej grupy, a także badanie zjawiska starzenia się osób z niepełnosprawnością, jak i procesu stawania się osobą niepełnosprawną w okresie starości. Wciąż niewiele wiemy

53 Ustawa z dnia 12 marca 2004 r. o pomocy społecznej, Dz.U. z 2015 r., poz. 163.

54 Ibidem. 
o sytuacji życiowej niepełnosprawnych osób starszych, toteż potrzebna jest rzetelna diagnoza oraz opracowanie sposobów wsparcia zarówno osób starszych, jak i ich najbliższego otoczenia.

Późna dorosłość, bez względu na to, jak dynamiczny ma przebieg, może i powinna być okresem o mozliwie wysokim poziomie jakości życia. Żeby tak mogło być, konieczna jest współpraca przedstawicieli wielu dyscyplin naukowych, owocująca rzetelnymi badaniami i postulatami dla praktyki. Starość, mimo że doczekała się licznych opracowań naukowych, nadal jest obszarem wymagającym eksploracji.

\section{Bibliografia}

Aspekty medyczne, psychologiczne, socjologiczne i ekonomiczne starzenia się ludzi w Polsce, red. P. Błędowski, PolSenior, Warszawa 2011.

BalcerzaK-PARAdowsKa B., Sytuacja osób niepetnosprawnych w Polsce, [w:] Raport IPiSS, nr 22, Warszawa 2002.

Bilikiewicz A., Psychiatria. Podręcznik dla studentów medycyny, Wydawnictwo Lekarskie PZWL, Warszawa 2006.

Bojanowska E., Opieka nad ludźmi starszymi, [w:] Przygotowanie do starości. Polacy wobec starzenia się, red. P. Szukalski, Fundacja Instytutu Spraw Publicznych, Warszawa 2009.

Centrum Systemów Informacyjnych Ochrony Zdrowia, Międzynarodowa Klasyfikacja Funkcjonowania, Niepetnosprawności i Zdrowia (ICF) oraz jej zastosowanie, Warszawa 2007.

CZARnecki P.S., Praca socjalna, Difin, Warszawa 2013.

Czekanowski P., Rodzina w życiu osób starszych i osoby starsze w rodzinie, [w:] Polska starość, red. B. Synak, Wydawnictwo Uniwersytetu Gdańskiego, Gdańsk 2002.

Duda K., Proces starzenia się, [w:] A. Marchewka, Z. Dąbrowski, J.A. Żołądź, Fizjologia starzenia się. Profilaktyka i rehabilitacja, Wydawnictwo Naukowe PWN, Warszawa 2012.

HaLiK J., Inwalidztwo i niepetnosprawność wśród osób starszych, Instytut Spraw Publicznych, Warszawa 1997.

HiLl R.D., Pozytywne starzenie się, Laurum, Warszawa 2009.

International Classification of Impairments, Disabilites and Handicaps, WHO, Genewa 1980.

International Classification of Functioning. Disability and Health, WHO, Genewa 2001.

JanuszKo L., Niepetnosprawność - aspekt epidemiologiczny i społeczny, [w:] Niepetnosprawni na progu wejścia Polski do Unii Europejskiej, red. M. Waszkowski, Polskie Towarzystwo Walki z Kalectwem, Warszawa 2004. 
KACPERCZYK A., Wsparcie społeczne w instytucjach opieki paliatywnej i hospicyjnej, Wydawnictwo Uniwersytetu Łódzkiego, Łódź 2006.

KiLIAn M., Geragogika specjalna w dobie starzenia się społeczeństw, [w:] Dylematy (niepetno)sprawności - rozważania na marginesie studiów kulturowo-społecznych, red. M. Dycht, L. Marszałek, Wydawnictwo Salezjańskie, Warszawa 2009.

Majewski T., Międzynarodowa Klasyfikacja Funkcjonowania, Niepetnosprawności i Zdrowia, „Praca i Rehabilitacja Niepełnosprawnych” 2008, nr 3-4(119-120).

Niesamodzielność. Studia z pedagogiki specjalnej, red. M. Sekułowicz, M. Oleniacz, Wydawnictwo Naukowe DWS, Wrocław 2012.

O sytuacji ludzi starszych, red. J. Hrynkiewicz, Rządowa Rada Ludnościowa, Warszawa 2012.

PrzybyŁka A., Problemy zdrowotne ludzi starych. Wybrane zagadnienia, „Polityka Społeczna" 2002, nr 8.

PuŻYŃSKI S., Depresje i zaburzenia afektywne, Wydawnictwo Lekarskie PZWL, Warszawa 2009.

Słownik jezzyka polskiego, red. W. Doroszewski, t. 8, PWN, Warszawa 1963.

Stan zdrowia ludności Polski w 2009 roku, GUS, Warszawa 2011.

Straś-Romanowska M., Późna dorostość. Wiek starzenia się, [w:] Psychologia rozwoju człowieka. Charakterystyka okresów życia człowieka, red. B. Harwas-Napierała, J. Trempała, Wydawnictwo Naukowe PWN, Warszawa 2004.

SzATUR-JAwORSKA B., Formy życia rodzinnego ludzi starych, „Polityka Społeczna” 2011, numer specjalny.

Ustawa z dnia 27 sierpnia 1997 r. o rehabilitacji zawodowej i społecznej oraz zatrudnieniu osób niepełnosprawnych, Dz.U. z 2011 r., nr 127, poz. 721 z późn. zm.

Ustawa z dnia 12 marca 2004 r. o pomocy społecznej, Dz.U. z 2015 r., poz. 163.

WieczorowsKa-ToBis K., NeUMANN-PODCZASKA A., Wptyw leków na sprawność funkcjonalna osób starszych na przykładzie upadków, [w:] Niesprawność u osób starszych. Zapobieganie - diagnostyka - terapia, red. A. Jakrzewska-Sawińska, Wielkopolskie Stowarzyszenie Wolontariuszy Opieki Paliatywnej Hospicjum Domowe, Poznań 2013.

Zych A.A., Zүсн B.M., Przekraczając "smuge cienia”. Szkice z gerontologii i tanatologii, Wydawnictwo Naukowe "Sląsk", Katowice 2013.

ŻaKowska-Wachelko B., Misztalscy A. I T., Czuma K., Opiekun osób starszych, Śląskie Stowarzyszenie Ad Vitam Dignam, Katowice 2010.

www.instytutobywatelski.pl/17845/lupa-instytutu/ageizm-dyskryminacja-zewzgledu-na-wiek [5.05.2015].

www.ue.katowice.pl/uploads/media/20_Z.Szweda-Lewandowska_Modele_opieki....pdf [5.05.2015].

www.ur.edu.pl/file/5671/04.pdf [5.05.2015]. 